\title{
Erratum zu: Auswirkungen von Mikroplastik
}

\section{Erratum zu:}

Kapitel 3 In: A. Fath, Mikroplastik kompakt, essentials, https://doi.org/10.1007/978-3-658-25734-7_3

Die originale Version dieses Buches wurde ohne Quellenangabe zur Abb. 3.2 publiziert. Die Quelle „Fraunhofer Umsicht“ ist nun ergänzt. 